\title{
ANALISA YURIDIS SOSIOLOGIS TENTANG PENERAPAN ASAS RESMI DAN PATUT DALAM PERKARA PERCERAIAN DITINJAU DARI PERSPEKTIF UNDANG-UNDANG NOMOR 12 TAHUN 201 TENTANG PEMBENTUKAN PERUNDANG UNDANGAN
}

\author{
SOCIOLOGICAL JURIDICAL ANALYSIS OF THE IMPLEMENTATION OF \\ OFFICIAL AND DECISIVE PRINCIPLES IN THE PROVINCE OF \\ DIVORCE REVIEWED FROM THE PERSPECTIVE OF LAW NUMBER 12 \\ OF 2011 CONCERNING ESTABLISHMENT OF LAW REGULATIONS
}

\author{
Saifuddin ${ }^{1}$, Jamaluddin ${ }^{2}$, Ramziati ${ }^{3}$ \\ ${ }^{1}$ Mahasiswa Program Studi Magister Hukum Universitas Malikussaleh/Panitera Muda \\ Permohonan pada Mahkamah Syar'iyah Takengon Kelas I.B \\ ${ }^{2}$ Guru Besar Ilmu Hukum Universitas Malikussaleh \\ ${ }^{3}$ Dosen Program Magister Ilmu Hukum Universitas Malikussaleh \\ Email: saifuddinbireuen9@gmail.com
}

\begin{abstract}
This study aims to conduct a sociological juridical analysis of the application of official and appropriate principles in the perspective of Law No. 12/2011 concerning the Formation of Legislation, using the normative juridical sociological research method. The results of the research that have been carried out show that the application of official and proper principles in the settlement of civil divorce cases in the Syar'iyah Court experiences sociological constraints, where summons or willingness to summons tend to be more often received by village officials: the village secretary, hamlet head or even the chief hallway, this happens because the village head/village is often not in the place, so the summons or the court summons are often handed over and received by the village secretary, hamlet head or even the head of the hall. This fact shows that the legality norm of a subpoena or divorce in a civil divorce trial (Article 390 HIR, Article 718 paragraph (1) RBg, Article 26 paragraph (3) PP Number 9 of 1975 and Article 138 Compilation of Islamic Law), which all this time it has become a guideline for implementing parties' summons, it is no longer appropriate to be applied in the jurisdiction of the Syar'iyah Court due to changes in social structure, so there needs to be a redefinition of the standard of validity of a subpoena or a summons.
\end{abstract} Keywords: Analysis, sociological juridical, official and appropriate principle, divorce, act

\section{Intisari}

Penelitian ini bertujuan untuk melakukan analisa secara yuridis sosiologis terhadap penerapan asas resmi dan patut dalam perspektif Undang-Undang Nomor 12 Tahun 2011 tentang Pembentukan Perundang-Undangan, dengan menggunakan metode penelitian yuridis normatif sosiologis. Hasil penelitian yang telah dilakukan menunjukkan bahwa penerapan asas resmi dan patut dalam penyelesaian perkara perdata perceraian di Mahkamah Syar'iyah mengalami kendala secara sosiologis, dimana surat panggilan sidang atau relaas panggilan 
cenderung lebih sering diterima oleh aparat kampung: sekretaris kampung, kepala dusun atau pun kepala lorong, hal tersebut terjadi karena kepala desa/kampung sering tidak berada di tempat, sehingga surat panggilan sidang atau relaas panggilan sidang sering diserahkan dan diterima oleh sekretaris kampung, kepala dusun atau pun kepala lorong. Fakta tersebut menunjukkan bahwa norma keabsahan sebuah surat panggilan sidang atau relaas panggilan sidang perkara perdata perceraian (Pasal 390 HIR, Pasal 718 ayat (1) RBg, Pasal 26 ayat (3) PP Nomor 9 Tahun 1975 dan Pasal 138 Kompilasi Hukum Islam), yang selama ini menjadi pedoman pelaksanaan pemanggilan para pihak, sudah tidak sesuai lagi diterapkan dalam wilayah yurisdiksi Mahkamah Syar'iyah akibat adanya perubahan struktur sosial kemasyarakatan, sehingga perlu adanya redefinisi tentang standar keabsahan sebuah surat panggilan sidang atau relaas panggilan.

Kata Kunci: Analisis yuridis sosiologis, asas resmi dan patut, perceraian, undang-undang

\section{A. Pendahuluan}

Pemanggilan para pihak adalah salah satu bagian terpenting dalam proses pemeriksaan dan penyelesaian perkara perceraian di Mahkamah Syar'iyah (Pengadilan Agama), dan hal tersebut dilakukan setelah adanya penetapan dan penunjukan oleh Ketua Mahkamah Syar'iyah (Pengadilan Agama) tentang Majelis Hakim yang ditunjuk untuk menangani sebuah perkara perceraian, dan setelah Ketua Majelis Hakim membuat penetapan tentang hari dan tanggal sidang pertama.

Dasar hukum dan tata cara pemanggilan para pihak dalam perkara perceraian di Mahkamah Syar'iyah (Pengadilan Agama) mengacu kepada ketentuan yang ditetapkan dalam Pasal 122, 388 dan Pasal 390 H.I.R, Pasal 146 dan Pasal 148 RBg, Pasal 26 ayat (3), Pasal 27 dan Pasal 28 PP Nomor 9 Tahun 1975, dan Pasal 138 sampai dengan Pasal 140 Kompilasi Hukum Islam ${ }^{1}$. Pemanggilan terhadap para pihak dalam perkara perceraian menganut asas resmi dan patut, yaitu sasaran atau objek pemanggilan harus tepat menurut tata cara yang telah ditentukan (resmi) dan memenuhi tenggang waktu yang patut (patut) ${ }^{2}$. Artinya bahwa surat panggilan sidang atau relaas panggilan itu harus diserahkan dan diterima lansung oleh para pihak yang bersangkutan di tempat kediamannya, atau kalau perkara tersebut dikuasakan, maka diserahkan kepada kuasanya dengan dialamatkan ke alamat kantornya, atau kepala kampung setempat, dan waktu pemanggilan itu dilaksanakan minimal 3 (tiga) hari sebelum hari dan tanggal sidang yang telah ditetapkan, dengan mempertimbangkan letak jauh dekatnya tempat tinggal para pihak yang berperkara ${ }^{3}$.

Sebuah putusan yang dibuat oleh hakim dalam perkara perdata perceraian sangat dipengaruhi oleh keabsahan surat panggilan sidang atau relaas panggilan dari perkara tersebut, sehingga tidak jarang Majelis Hakim terpaksa harus

${ }^{1}$ M. Yahya Harahap, 2007, Kedudukan Kewenangan dan Acara Peradilan Agama, Jakarta: Sinar Grafika, hlm..226-227.

${ }^{2}$ Ibid,.

${ }^{3}$ Abdul Manan, 2008, Penerapan Hukum Acara Perdata di Lingkungan Peradilan Agama, Jakarta: Prenada Media Group, hlm. 136-137.

Suloh: Jurnal Fakultas Hukum Universitas Malikussaleh,, Vol. 7, No. 1, April 2019, pp. 78 - 89. 
menunda sidang dan memerintahkan kepada jurusita/jurusita pengganti yang ditunjuk untuk melakukan pemanggilan ulang terhadap para pihak, dan hal tersebut dengan pertimbangan bahwa surat panggilan tidak sah karena belum memenuhi unsur resmi dan patut, serta pihak yang dipanggil pun ternyata tidak datang menghadap di persidangan sesuai dengan hari dan tanggal yang telah ditentukan.

Salah satu penyebab tidak sahnya surat panggilan sidang atau relaas panggilan yang disampaikan kepada para pihak yang berperkara adalah dikarenakan surat panggilan atau relaas panggilan tersebut tidak diterima dan ditanda tangani langsung oleh para pihak atau kepala kampung setempat namun diterima dan ditanda tangani oleh sekretaris kampung, kepala urusan (Kaur) kantor kepala kampung, atau kepala dusun setempat. kondisi tersebut terjadi akibat adanya perubahan dalam struktur pranata sosial dan struktur organisasi pemerintahan desa/kampung yang mengenal adanya struktur jabatan sekretaris kampung, kepala urusan (Kaur) dan kepala dusun, sehingga saat mana kepala kampung tidak berada di tempat, maka segala urusan administrasi yang menyangkut dengan kepentingan warga masyarakat, diambil alih dan diselesaikan oleh sekretaris kampung, kepala urusan (Kaur) dan kepala dusun. Demikian juga saat mana adanya penyampaian surat panggilan sidang atau relaas panggilan sidang yang dilakukan oleh jurusita atau jurusita pengganti dari Mahkamah Syar'iyah (Pengadilan Agama), bilamana ternyata para pihak atau kepala kampung tidak berada di tempat, maka sekretaris kampung, kepala urusan (Kaur) dan kepala dusun, atas dasar perintah dan mandat yang diberikan oleh kepada kampung menerima dan menanda tangani surat panggilan atau relaas panggilan tersebut.

Fakta tersebut di atas menjadi latar belakang dari penulisan artikel ini, dengan tujuan untuk membahas tentang: penerapan asas resmi dan patut dalam proses pemeriksaan perkara perdata perceraian di Mahkamah Syar'iyah, dan analisa yuridis sosiologis tentang penerapan asas resmi dan patut dalam perspektif Undang-Undang Nomor 12 Tahun 2011 Tentang Pembentukan PerundangUndangan.

Artikel ini adalah murni sebagai penelitian pertama dan belum ada penelitian sebelumnya yang memiliki kesamaan dengan penelitian ini, baik dari segi judul maupun rumusan permasalahan yang menjadi topik kajiannya. Dari hasil penelusuran yang dilakukan didapatkan fakta bahwa para peneliti lain telah melakukan penelitian dengan judul sebagai berikut:

1. Efektifitas sistem peradilan sederhana, cepat dan biaya ringan di lingkungan Pengadilan Umum, dengan rumusan masalah: apakah fakor-faktor yang mempengaruhi efektifitas sistem peradilan sederhana, cepat dan biaya ringan;

2. Kedudukan relaas panggilan terhadap putusan verstek di Pengadilan Agama Makassar, dengan rumusan masalah: bagaimana proses pemanggilan para pihak berperkara di pengadilan agama, bagaimana proses pemeriksaan putusan verstek di Pengadilan Agama, bagaimana kedudukan relaas panggilan terhadap putusan verstek di Pengadilan Agama Makassar;

3. Tata cara pemanggilan para pihak yang berperkara Pengggugat/Tergugat yang terlibat dalam perkara perkara di Pengadilan Negeri (Penerapan Pasal 388 jo 
Pasal 390 HIR), dengan rumusan masalah: bagaimana prinsip-prinsip gugatan perdata, bagaimana prosedur mengajukan gugatan di Pengadilan Negeri, bagaimana tata cara pemanggilan yang sah dalam persiapan persidangan perkara menurut undang-undang;

\section{B. Pembahasan}

\section{Kajian Yuridis Sosiologis}

Pelaksanaan pemanggilan para pihak dalam perkara perceraian yang dilakukan oleh jurusita atau jurusita pengganti di lingkungan Mahkamah Syar'iyah cenderung mengalami hambatan secara tehnis, hal tersebut terjadi karena petugas jurusita atau jurusita pengganti yang ditugaskan mengantarkan surat panggilan sering tidak bertemu dengan para pihak atau pun kepala kampung setempat, namun bertemu dengan aparatur kampung lainnya, seperti sekretaris kampung, Kaur kantor kepala kampung maupun kepala dusun tempat tinggal para pihak yang berperkara ${ }^{4}$. Sampai dengan saat ini pedoman yang dijadikan ukuran keabsahan sebuah surat panggilan sidang atau relaas panggilan sidang adalah jika surat panggilan sidang atau relaas panggilan tersebut diterima dan ditanda tangani oleh para pihak secara langsung atau kepala kampung setempat bilamana tidak bertemu langsung dengan para pihak yang berperkara (Pasal 122, 388 dan Pasal 390 H.I.R, Pasal 146 dan Pasal 148 RBg, Pasal 26 ayat (3), Pasal 27 dan Pasal 28 PP Nomor 9 Tahun 1975, dan Pasal 138 sampai dengan Pasal 140 Kompilasi Hukum Islam) 5 .

Fakta tersebut di atas menjadi bukti bahwa jurusita atau jurusita pengganti yang bertugas mengantarkan surat panggilan sidang atau relaas panggilan mengalami kendala secara tehnis administratif. Seharusnya kendala tersebut tidak perlu terjadi bilamana surat panggilan sidang atau relaas panggilan secara normatif dibenarkan dan menjadi sah jika diterima dan ditanda tangani oleh sekretaris kampung, Kaur kantor kepala kampung maupun kepala dusun. Norma yang mengatur bahwa surat panggilan sidang atau relaas panggilan sidang hanya sah jika diterima oleh para pihak atau kepala kampung, telah membuat jurusita atau jurusita pengganti merasa kesulitan menjalankan tugasnya, padahal idealnya sebuah aturan yang dibuat itu harus dapat memberikan kepastian secara hukum dan keadilan bagi masyarakat.

Dalam konteks kajian filsafat, hukum diharapkan mampu memberikan dan memenuhi aspek ontologi yaitu menciptakan ketentraman dan kebahagiaan bagi hidup manusia, sebagai sutau tujuan yang ingin dicapai setiap manusiadan merupakan hakikat dari hukum itu sendiri. Menurut Theo Huijbers hakikat hukum juga menjadi sarana bagi penciptaan suatu aturan masyarakat yang adil (rapport du droit, inbreng van recht). Dalam aspek epistimologi hukum dilahirkan melalui suatu metode tertentu yang sistematis dan objektif serta selalu dilakukan pengkajian-pengkajian, sehingga melahirkan ilmu hukum yang merupakan bagian dari ilmu pengetahuan. Dari aspek aksiologi hukum memiliki nilai-nilai yang

4 Hasil wawancara dengan Hefa Lizayanti dan Desi Maulidar, jurusita pengganti Mahkamah Syar'iyah Takengon, pada tanggal 05 Juli 2019.

${ }^{5}$ M. Yahya Harahap, 2007, Op.Cit, hlm. 226-227. 
harus ditaati dan dilaksanakan oleh setiap manusia dalam kehidupan berbangsa dan bernegara ${ }^{6}$.

Norma dalam hukum adalah sebuah nilai yang berfungsi sebagai sifat atau kualitas dari sesuatu yang bermanfaat bagi kehidupan manusia, baik lahir maupun bathin. Ada 4 (empat) nilai yang terkandung dalam hukum, yaitu nilai teori, nilai sosial, nilai ekonomi, dan nilai dalam pengambilan putusan. Dalam konteks nilai teori: bahwa hukum melahirkan teori-teori yang terus tumbuh dan berkembang sesuai dengan perubahan dan perkembangan manusia dan perkembangan ilmu pengetahuan lainnya, termasuk teknologi dan informasi. Teori-teori tersebut akan selalu mengilhami di dalam setiap pembentukan setiap peraturan perundangundangan yang dibuat. Dalam konteks nilai sosial: bahwa hukum memberikan dampak yang luar biasa dalam pergaulan sosial manusia, manusia bisa saling menghargai, manusia dapat melaksanakan kewajiban dan memperoleh haknya dengan baik, manusia dapat hidup bersama di tengah-tengah masyarakat. Dalam konteks nilai ekonomi: bahwa hukum memberikan jaminan kepada manusia untuk hidup dan memenuhi kebutuhan hidupnya dengan baik, baik kebutuhan sandang, pangan, papan dan kebutuhan-kebutuhan lainnya. Manusia dapat bekerja dan mengejar tingkat ekonomi kehidupannya dengan baik tanpa diganggu oleh manusia lainnya. Dalam konteks nilai pengambilan keputusan: bahwa hukum dijadikan dasar oleh para pengambil keputusan dalam mengeluarkan setiap keputusan dan kebijakan yang dibuat, sehingga terhindar dari kesewenangwenangan. Hukum dijadikan sebagai landasan berpijak oleh setiap pejabat di negara ini. Nilai ini sejalan dengan konsep negara yang dianut di Indonesia ${ }^{7}$.

Dari aspek nilai teori, norma keabsahan panggilan sidang perkara perceraian sebagaimana diatur dalam Pasal 122, 388 dan Pasal 390 H.I.R, Pasal 146 dan Pasal 148 RBg, Pasal 26 ayat (3), Pasal 27 dan Pasal 28 PP Nomor 9 Tahun 1975, dan Pasal 138 sampai dengan Pasal 140 Kompilasi Hukum Islam, ternyata tidak dapat mengakomodir dan menyesuaikan dengan perubahan dan perkembangan yang terjadi dalam pranata sosial kemasyarakatan dan tatanan struktur organisasi pemerintahan desa/kampung yang ada saat ini di Indonesia. hal tersebut dikuatkan dengan kenyataan bahwa sampai saat ini tidak ada satu pun aturan atau regulasi normatif yang dapat dijadikan sebagai payung hukum untuk membuka peluang bagi sekretaris kampung, kepala urusan (Kaur) pemerintahan kampung atau pun kepala dusun untuk dapat menerima dan menanda tangani surat panggilan sidang atau relaas panggilan. Sekali pun dalam forum-forum internal Mahkamah Agung Republik Indonesia sering dibahas tentang kemungkinan untuk merubah dan memperluas tentang defenisi keabsahan suatu surat panggilan sidang atau relaas panggilan, namun sampai saat ini belum ada satu peraturan perundang-undangan pun yang dapat dijadikan sebagai dasar hukum untuk membenarkan sekretaris kampung, kepala urusan (Kaur) kantor kepala kampung maupun kepala dusun, menerima dan menanda tangani surat panggilan sidang.

Suatu aturan hukum yang dibuat tentu tidak terlepas dari aspek yuridis, historis, filosofis dan sosiologis. Oleh karenanya untuk dapat memahami suatu

${ }^{6}$ Theo Huijbers, 1995, Filsafat Hukum, Yogyakarta: Kanisius, hlm. 75.

${ }^{7}$ Muchammad Ali Safa'at, 2014, Anotasi Pemikiran Hukum (Dalam Perspektif Filsafat Hukum), Malang: Universitas Brawijaya Press (UB Press), hlm. 90-91..

Suloh: Jurnal Fakultas Hukum Universitas Malikussaleh,, Vol. 7, No. 1, April 2019, pp. 78 - 89. 
hukum yang ada maka haruslah dilihat dan dipahami secara utuh, yaitu harus dilihat tidak hanya dari aspek yuridis dan historis saja, namun juga harus dilihat dan dipahami dari aspek filosofis dan sosiologisnya juga. Demikian halnya juga dengan aturan hukum yang mengatur tentang standar keabsahan sebuah surat panggilan sidang atau relaas panggilan. Lahirnya sejumlah aturan tentang keabsahan panggilan, yaitu: Pasal 122, 388 dan Pasal 390 H.I.R, Pasal 146 dan Pasal 148 RBg, Pasal 26 ayat (3), Pasal 27 dan Pasal 28 PP Nomor 9 Tahun 1975, dan Pasal 138 sampai dengan Pasal 140 Kompilasi Hukum Islam, juga sangat dipengaruhi oleh kondisi historis dan sosiologis yang ada saat sejumlah aturan tersebut dibuat. Oleh karenanya wajar jika sejumlah norma yang ditetapkan tersebut, saat ini terasa sudah tidak sesuai lagi dengan kondisi sosiologis masyarakat Indonesia saat ini, sehingga kemudian dirasakan perlu untuk dilakukan langkah-langkah untuk memperbaharui dan melakukan redefenisi agar aturan tersebut dapat efektif berlaku, karena menurut Hans Kelsen, suatu aturan hukum baru dapat dikatakan efektif jika dapat diterapkan dan dapat diterima oleh masyarakat luas secara terus menerus ${ }^{8}$; “...A legal norm becomes valid before becomes effective, that is, before it is applied and obeyed; a law court that applies a statute immediatly after promulgation-therefore before the statute had a chance to become "effective"- applies a valid legal norm. But a legal norm is no longer considered to be valid, if it remains permanently ineffective. Effectiveness is a condition of validity in the sense that effectiveness has to join the positing of a legal norm if the norm is not to lose its validity..".

Ada 2 (dua) syarat yang harus dipenuhi agar suatu aturan hukum yang dibuat itu dapat efektif, yaitu?:

1. Kaidah hukum tersebut harus dapat diterapkan;

2. Kaidah hukum tersebut harus dapat diterima oleh masyarakat.

Menurut J.W Haris, parameter yang daapat digunakan untuk mengukur apakah suatu aturan hukum itu dapat efektif berlaku dalam masyarakat, dapat dipedomani kepada beberapa asumsi sebagai berikut:

1. Apakah aturan hukum tersebut bersesuaian (conformity) dengan aturan tertentu yang tingkatnya lebih tinggi. Aturan hukum tersebut tidak dalam keadaan "di luar jalur" (ultra vires);

2. Apakah aturan hukum tersebut merupakan bagian yang konsisten (subsistem) dengan bidang pengaturan yang sudah ada saat ini;

3. Apakah aturan hukum tersebut bersesuaian dengan kenyataan sosial dalam masyarakat (aspek sosiologis), sehingga berlaku efektif dalam masyarakat;

4. Apakah dalam aturan hukum tersebut terdapat kecenderungan internal untuk dihormati (atas dasar moral dan politik);

5. Apakah aturan hukum tersebut merupakan bagian dari kenyataan normatif yang transedental (aspek ontologis) ${ }^{10}$.

Menurut hemat penulis, aspek sosiologis merupakan aspek prioritas yang harus benar-benar diperhatikan dari setiap aturan hukum yang dibuat, sehingga

${ }^{8}$ Munir Fuady, 2013, Teori Teori Besar Dalam Hukum (Grand Theory), Jakarta: Kencana Prenada Media Group, hlm. 117.

${ }^{9}$ Ibid,.

${ }^{10}$ Ibid, hlm. 111.

Suloh: Jurnal Fakultas Hukum Universitas Malikussaleh,, Vol. 7, No. 1, April 2019, pp. 78 - 89. 
aturan hukum yang dibuat itu akan benar-benar menyentuh rasa keadilan bagi masyarakat sebagai subyek hukum. Menurut Samuel Mermin, dalam konteks kajian sosiologi hukum, hukum itu ditempatkan sebagai objek hukum dengan meneropong dari luar hukum dengan menggunakan konsep-konsep berbagai ilmu sosial. Menurut Samuel Mermin: "The life of the law has not been logic, it has been experience"(hukum bukan sekedar sebagai sesuatu yang logis saja, melainkan yang lebih penting lagi hukum merupakan sesuatu yang dialami secara nyata dalam kehidupan) ${ }^{11}$.

Menurut Rescoe Pound, problem utama yang menjadi perhatian utama saat ini dari para yuris sosiologis adalah untuk memungkinkan dan mendorong pembuatan hukum, dan juga menafsirkan dan menerapkan aturan-aturan hukum serta untuk membuat lebih berharganya fakta-fakta sosial di atas mana hukum harus berjalan dan untuk mana hukum itu diterapkan, ("...the main problem to wich socioogical jurists are addering them selves today is to enable and to compel law making, and also interpretation and application of legal rules, to make more account, an more intelegent account, of the social fact upon which law must proceed and to which it is to be applied." $)^{12}$.

Menurut Vilhelm Aubert, kajian aspek sosiologi dari sebuah aturan hukum sangatlah penting karena merupakan alat bantu dari suatu studi hukum. analisa tentang fenomena-fenomena yang diatur oleh hukum, dapat membantu para pembuat undang-undang atau pengadilan dalam membuat putusannya, dan yang benar-benar penting adalah fungsi kritis dari sosiologi hukum adalah sebagai suatu penolong dalam meningkatkan kesadaran kaum profesional hukum dalam menjalankan fungsi-fungsi kemasyarakatannya ${ }^{13}$.

Menurut penulis, konsep pemikiran Vilhelm Aubert tersebut sangat relevan dengan apa yang sekarang menjadi salah satu asas yang harus dipedomani oleh hakim di Pengadilan dalam menangani dan memutuskan sebuah perkara, yaitu asas yang mewajibkan bagi hakim untuk memperhatikan hal-hal yang hidup dalam masyarakat, dan semua itu dimaksudkan adalah rangka memberikan keadilan yang hakiki bagi masyarakat sebagai subyek hukum. Demikian halnya juga dengan aturan hukum yang dibuat tentang tata cara dan keabsahan sebuah surat panggilan atau relaas panggilan sidang, harus benar-benar memperhatikan nilai-nilai yang hidup dan berkembang dalam masyarakat, baik dalam konteks perubahan pranata sosial kemasyarakatan maupun perubahan struktur organisasi pemerintahan desa atau kampung, sehingga 2 (dua) jenis perubahan tidak menjadi penghalang bagi majelis hakim yang menangani dan memutuskan perkara perceraian di Pengadilan Agama atau Mahkamah Syar'iyah. Menurut Rescou Pound, yang terpenting dari sebuah aturan hukum yang dibuat adalah tidak semata-mata studi tentang doktrin yang telah dibuat dan telah dikembangkan, melainkan apa efek sosial dari doktrin-doktrin yang telah dibuat dan dikembangkan, tetapi apa efek sosial dari doktrin hukum yan telah dihasilkan dari masa silam dan bagaimana memprodukkan mereka Inti dari kajian sosiologi

11 Achmad Ali-Wiwie Heryani, 2012, Menjelajahi Kajian Empiris Terhadap Hukum, Jakarta: Kencana Prenada Media Group, hlm. 7-8.

12 Ibid, hlm. 9.

13 Ibid,. 
hukum menurut Rescou Pound adalah menitik beratkan pada usaha untuk lebih mengefektifkan tercapainya tujuan hukum ${ }^{14}$.

Menurut Satjipto Rahardjo, untuk dapat memahami karakteristik dari sosiologi hukum, maka dapat dipahami dengan penjelasan sebagai berikut: untuk dapat memahami permasalahan yang dikemukakan dalam kitab ujian ini dengan seksama, orang hanya dapat melakukan melalui pemanfaatan teori sosial mengenai hukum. Teori ini bertujuan untuk memberikan penjelasan mengenai hukum dengan mengarahkan pengkajiannya keluar dari sistem hukum. Kehadiran hukum di tengah tengah masyarakat, baik itu menyangkut soal penyusunan sistemnya, memilih konsep atau pengertian, menentukan subjek yang diaturnya, maupun soal bekerjanya hukum itu, dicoba untuk dijelaskan dalam hubungannya dengan tertib sosial yang lebih luas. Apabila disini boleh dipakai istilah "sebabsebab sosial", maka sebab-sebab yang demikian itu hendak ditemukan baik dalam kekuatan budaya, politik, ekonomi, atau sebab-sebab sosial yang lain ${ }^{15}$.

Kajian sosiologi hukum menitik beratkan tentang bagaimana hukum melakukan interaksi dalam masyarakat dan menekankan perhatian terhadap kondisi-kondisi sosial yang berpengaruh bagi pertumbuhan hukum, bagaimana pengaruh perubahan sosial terhadap hukum, dan bagaimana hukum mempengaruhi masyarakat. Oleh karenanya, adalah hal menarik untuk dianalisa saat mana aturan hukum tentang keabsahan pemanggilan terhadap para pihak, yang mengatur batasan sah atau tidaknya suatu panggilan sidang atau relaas panggilan, ternyata dalam perkembangan dan fakta perubahan pranata sosial kemasyarakatan dan perubahan struktur tata pemerintahan desa/kampung, telah menjadi sebuah kendala sendiri bagi jurusita atau jurusita pengganti dalam menjalankan tugas pemanggilan terhadap para pihak yang berperkara.

\section{Kajian Perspektif Undang-Undang Nomor 12 Tahun 2011 tentang Pembentukan Perundang-Undangan}

Saat mana kita bermaksud untuk menganalisa tentang efektifitas penerapan suatu aturan hukum, maka hal penting yang senantiasa harus menjadi perhatian adalah unsur-unsur penting dalam pembentukan suatu aturan hukum, sehingga aturan hukum yang dibuat dapat benar-benar bermanfaat dan menjadi sebuah jawaban atas masalah yang ada dalam masyarakat sebagai subyek hukum.

Dalam konteks pembahasan tentang aturan hukum pemanggilan para pihak dalam perkara perceraian, maka menurut penulis, hal yang sangat relevan untuk dilakukan guna memahami, menilai dan mengukur apakah norma yang mengatur tentang keabsahan sebuah panggilan sidang atau relaas panggilan, sebagaimana yang ditetapkan dalam Pasal 390 HIR, Pasal 718 ayat (1) RBg, Pasal 26 ayat (3) PP Nomor 9 Tahun 1975 dan Pasal 138 Kompilasi Hukum Islam, apakah masih relevan dengan perkembangan sosial kemasyarakatan bangsa Indonesia dan juga perkembangan serta perubahan struktur organisasi pemerintahan desa/kampung yang ada dewasa ini, adalah melakukan kajian dengan menggunakan pendekatan

\footnotetext{
${ }^{14}$ Ibid, hal. 11-12.

${ }^{15}$ Ibid, hal. 12.
} 
analisa dari sudut pandang Undang-Undang Nomor 12 Tahun 2011 tentang Pembentukan Perundang-Undangan.

Pasal 5 Undang-Undang Nomor 12 Tahun 2011 tentang Pembentukan Perundang-Undangan menegaskan bahwa suatu aturan hukum yang dibuat haruslah didasarkan kepada asas-asas dan penjelasan per pasal sebagai berikut:

a. Asas kejelasan tujuan;

Bahwa setiap pembentukan peraturan perundang-undangan harus mempunyai tujuan yang jelas yang hendak dicapai.

b. Asas kelembagaan atau organ pembentuk yang tepat;

Bahwa setiap jenis peraturan perundang-undangan harus dibuat oleh lembaga/pejabat pembentuk peraturan perundang-undangan yang berwenang. Peraturan perundang-undangan tersebut dapat dibatalkan atau batal demi hukum, bila dibuat oleh lembaga/pejabat yang tidak berwenang.

c. Asas kesesuaian antara jenis dan materi muatan;

Bahwa dalam pembentukan peraturan perundang-undangan harus benarbenar memperhatikan materi muatan yang tepat dengan jenis peraturan perundang-undangan.

d. Asas dapat dilaksanakan;

Bahwa dalam setiap pembentukan perundang-undangan harus memperhitungkan efektifitas peraturan peraturan perundang-undangan tersebut di dalam masyarakat, baik secara filosofis, yuridis, maupun sosiologis.

e. Asas kedayagunaan dan kehasilangunaan;

Bahwa setiap peraturan perundang-undangan yang dibuat karena memang benar-benar dibutuhkan dan bermanfaat dalam mengatur kehidupan bermasyarakat, berbangsa dan bernegara.

f. Asas kejelasan rumusan;

Bahwa setiap peraturan perundang-undangan harus memenuhi persyaratan teknis penyusunan peraturan perundang-undangan, sistematika dan pilihan kata atau terminologi, serta bahasa hukumnya jelas dan mudah dimengerti, sehingga tidak menimbulkan pelbagai macam interpretasi dalam pelaksanaannya.

g. Asas keterbukaan;

Bahwa dalam proses pembentukan peraturan perundang-undangan mulai dari perencanaan, persiapan, penyusunan, dan pembahasan bersifat transparan dan terbuka, sehingga seluruh lapisan masyarakat mempunyai kesempatan yang seluas luasnya untuk memberikan masukan dalam proses pembuatan peraturan perundang-undangan.

Sementara Pasal 6 Undang-Undang Nomor 10 Tahun 2004 Tentang Pembentukan Perundang-Undangan menjelaskan bahwa ada beberapa asas yang harus diperhatikan dalam penentuan materi muatan peraturan perundangundangan, beserta penjelasan per pasal yaitu:

a. Asas pengayoman;

Bahwa setiap peraturan perundang-undangan harus berfungsi memberikan perlindungan dalam rangka menciptakan ketentraman dalam masyarakat. 
b. Asas kemanusiaan;

Bahwa setiap materi muatan peraturan perundang-undangan harus mencerminkan perlindungan dan penghormatan hak-hak asasi manusia serta harkat dan martabat setiap warga negara dan penduduk Indonesia secara proposional.

c. Asas kebangsaan;

Bahwa setiap materi muatan perundang-undangan harus mencerminkan sifat dan watak bangsa Indonesia yang pluralistik (kebinekaan) dengan tetap menjaga prinsip negara kesatuan Republik Indonesia.

d. Asas kekeluargaan;

Bahwa setiap materi muatan perundang-undangan harus mencerminkan musyawarah untuk mencapai mufakat dalam setiap pengambilan keputusan.

e. Asas kenusantaraan;

Bahwa setiap materi muatan perundang-undangan senantiasa memperhatikan kepentingan seluruh wilayah Indonesia dan merupakan bagian dari sistem hukum nasional yang berdasarkan Pancasila.

f. Asas bhineka tunggal ika;

Bahwa materi muatan perundang-undangan harus memperhatikan keragaman penduduk, agama, suku dan golongan, kondisi khusus daerah, dan budaya khususnya yang menyangkut masalah-masalah sensitif dalam kehidupan bermasyarakat, berbangsa dan bernegara.

g. Asas keadilan;

Bahwa setiap materi muatan perundang-undangan harus mencerminkan keadilan secara proposional bagi setiap warga negara tanpa kecuali.

h. Asas kesamaan kedudukan dalam hukum dan pemerintahan;

Bahwa setiap materi muatan perundang-undangan tidak boleh berisi hal-hal yang sifatnya membedakan berdasarkan latar belakang antara lain agama, suku, ras, golongan, gender atau status sosial.

i. Asas ketertiban dan kepastian hukum;

Bahwa setiap materi muatan perundang-undangan harus dapat menimbulkan ketertiban dalam masyarakat melalui jaminan adanya kepastian hukum.

j. Asas keseimbangan, keserasian dan keselarasan;

Bahwa setiap materi muatan perundang-undangan harus mencerminkan keseimbangan, keserasian, dan keselarasan, antara kepentingan individu dan masyarakat dengan kepentingan bangsa dan negara.

Dalam konteks aturan hukum tentang keabsahan pemanggilan para pihak dalam perkara perceraian, maka menurut hemat Penulis materi muatan yang ada dalam sejumlah pasal dan aturan hukum yang terkait (Pasal 390 HIR, Pasal 718 ayat (1) RBg, Pasal 26 ayat (3) PP Nomor 9 Tahun 1975 dan Pasal 138 Kompilasi Hukum Islam), sudah saatnya untuk dilakukan pembaharuan, hal tersebut mengingat bahwa ternyata efektifitas peraturan tersebut di dalam masyarakat, baik secara filosofis, yuridis, maupun sosiologis, sudah tidak relevan lagi, akibat adanya perubahan dan perkembangan dalam strata sosial kemasyarakatan dan tata struktur organisasi pemerintahan desa/kampung di Indonesia dewasa ini.

Menurut Yuliandri, untuk dapat memahami secara baik tentang muatan materi sebuah aturan hukum yang ada, maka perlu dibaca dan dipelajari tentang 
Naskah Akademik dari aturan hukum tersebut, karena di dalam Naskah Akademik dapat ditemukan sejumlah keterangan tentang pertimbangan, alasan, tujuan dan substansi suatu aturan hukum. Naskah Akademik merupakan salah satu bentuk perwujudan asas-asas pembentukan peraturan perundang-undangan yang baik, khususnya terkait pelaksanaan asas tujuan yang jelas (het beginsel van duidelijke doelstelling), asas perlunya pengaturan (het noodzakelijkheids beginsel), dan asas dapat dilaksanakan (het beginsel van uitvoerbaarheid), karena sebuah aturan hukum yang baik adalah aturan hukum yang dapat memperhitungkan efektifitasnya dalam masyarakat, baik secara filosofis, yuridis maupun sosiologis ${ }^{16}$. Dengan kata lain bahwa sebuah aturan hukum yang dibuat itu sejatinya memang karena benar-benar dibutuhhkan dan diharapkan akan memberikan manfaat dalam mengatur kehidupan bermasyarakat, berbangsa dan bernegara $^{17}$. Demikian halnya juga, menurut penulis, terkait dengan aturan hukum yang mengatur tentang keabsahan sebuah surat panggilan atau relaas panggilan dalam perkara perceraian, harus benar-benar memberikan manfaat dalam proses pemeriksaan perkara dalam perkara perceraian di Pengadilan Agama/Mahkamah Syar'iyah, sehingga pada gilirannya akan memberikan rasa keadilan bagi para pihak yang berperkara atau para pencari keadilan terkait dengan proses perkara yang dihadapinya, Amiin.

C. Penutup

1. Muatan materi aturan normatif tentang keabsahan sebuah panggilan sidang atau relaas panggilan (dalam perkara perdata perceraian), dalam pembentukannya sangat dipengaruhi oleh aspek yuridis, historis, filosofis dan sosiologis, sehingga sangatlah bisa dimaklumi jika kemudian saat ini terasa kurang sesuai untuk diterapkan terkait dengan adanya perubahan pranata sosial kemasyarakatan dan tata struktur pemerintahan desa/kampung;

2. Undang-Undang Nomor 10 Tahun 2004 Tentang Pembentukan PerundangUndangan mengamanatkan bahwa setiap materi muatan aturan hukum haruslah terkandung di dalamnya asas tujuan yang jelas dan asas dapat dilaksanakan, agar setiap materi aturan hukum yang dibuat dapat efektif dan dapat dirasakan manfaatnya di dalam masyarakat.

\section{DAFTAR PUSTAKA}

M. Yahya Harahap, 2007, Kedudukan Kewenangan dan Acara Peradilan Agama, Jakarta: Sinar Grafika

Abdul Manan, 2008, Penerapan Hukum Acara Perdata di Lingkungan Peradilan Agama, Jakarta: Prenada Media Group

16 Yuliandri, 2013, Asas-Asas Pembentukan Peraturan Perundang-Undangan Yang Baik, Gagasan Pembentukan Undang-Undang Berkelanjutan, Jakarta: RajaGrafindo Persada, hlm.169170.

${ }^{17}$ Ibid., hlm. 170.

Suloh: Jurnal Fakultas Hukum Universitas Malikussaleh, Vol. 7, No. 1, April 2019, pp. 78 - 89. 
Theo Huijbers, 1995, Filsafat Hukum, Yogyakarta: Kanisius

Muchammad Ali Safa'at, 2014, Anotasi Pemikiran Hukum (Dalam Perspektif Filsafat Hukum), Malang: Universitas Brawijaya Press (UB Press)

Munir Fuady, 2013, Teori Teori Besar Dalam Hukum (Grand Theory), Jakarta: Kencana Prenada Media Group

Achmad Ali-Wiwie Heryani, 2012, Menjelajahi Kajian Empiris Terhadap Hukum, Jakarta: Kencana Prenada Media Group

Yuliandri, 2013, Asas-Asas Pembentukan Peraturan Perundang-Undangan Yang Baik, Gagasan Pembentukan Undang-Undang Berkelanjutan, Jakarta: RajaGrafindo Persada 